\title{
Clinicopathological Studies on Theileria annulata Infection in Siwa Oasis, Egypt
}

\author{
T.R. Abou-El-Naga' ${ }^{1}$, T. A. Abdou' ${ }^{2}$ Mona A. Mahmoud ${ }^{1}$ \\ ${ }^{1}$ Animal Health Department, Desert Research Center, Cairo, Egypt \\ ${ }^{2}$ Faculty of Veterinary Medicine Cairo University, Cairo, Egypt
}

\begin{abstract}
One hundred and twenty five (125) cross and native cattle breeds were examined for prevalence of $T$. annulata infection for the first time in Siwa Oasis and evaluated ts effect on some blood constituents before and after treatment with buparvaquone. The prevalence of tropical theileriosis was 40.3 and $29.4 \%$ in cross and native breed respectively using blood smear examination. Immunofluorescent antibody technique (IFAT) could identify $T$. annulata in $80.7 \%$ of cross breed and $70.5 \%$ of native cattle. In addition, there was seasonal variation in prevalence. The tick species $\boldsymbol{H}$. anatolicum was recovered from $65.6 \%$ of examined cattle. Cattle clinically infected with $T$. annulata had significantly low levels of total proteins, albumin, magnesium, potassium and iron concentrations $(\mathrm{P} \leq 0.05)$ but AST, L $\gamma$ glutamyl transferase activities, total, direct and indirect bilirubin, creatinine levels were significantly high $(\mathrm{P} \leq \mathbf{0 . 0 5})$. Buparvaquone was effective against both stages of $T$. annulata and succeed to control fever and temperature returned to normal range by $7^{\text {th }}$ day post treatment. In addition, some serum elements returned to its normal values post treatment especially in native but not in cross breed cattle. In brief, our data showed that tropical theileriosis is prevalent in Siwa Oasis especially among cross breed cattle and the disease has some effects on hepatic and renal functions. There is a need for using immunization methods to reduce the losses from the disease.
\end{abstract}

Tropical theileriosis is severe, often fatal disease of cattle caused by Theileria annulata. The parasite is transmitted trans-staidly by the bite of Hyalomma spp. Ticks are distributed from Morocco eastwards across North Africa, the near and Middle East to India, Central Asia and China (Norval et al., 1992 and Payne and Wilson, 1999). Clinical T. annulata infection is traditionally diagnosed by the demonstration of schizont-infected cells in the superficial lymph nodes draining the site of the tick bite, or of piroplasms in peripheral blood vessels (Anon, 1997). In recovered carrier animal, only the piroplasm stage can be demonstrated, often with great difficulty. Siwa Oasis is a virgin area and considered one of the most promising areas for agricultural expansion in Egypt. Many problems face cattle farming in Siwa including parasitic infections especially tick-borne diseases. Theileriosis is one of the most devastating blood parasites affecting cattle in Egyptian Oases (Harfoush, 2001 and Saleh and Mahran, 2003). Indirect fluorescent antibody technique (IFAT) has been effectively employed by many authors as rapid and accurate serological test for detection of bovine theileriosis (Farah, 1995; Handemir and Dik, 1998 and Lawal et al.,
1998). The aim of this study was directed to investigate tropical theileriosis for the first time in Siwa Oasis and clarifying its effects on some blood biochemical constituents as well as treatment of diseased cattle and evaluate the effect of buparvaquone on the health of treated animals.

\section{Materials and Methods}

Study area and examined animals. Siwa Oasis lies south to Matrouh Governorate in the western desert $306 \mathrm{~km}$ far from Mersa Matrouh. One hundred and Twenty five 1-3 years old cattle including 57 local and 68 crossbred cattle were subjected to careful clinical examination as well as investigation of theileriosis after (Rosenberger, 1979).

Blood and serum samples. Blood samples were collected from jugular vein. Serum samples were divided into two portions, one for IFAT and the other was used for biochemical analysis. Blood of ear veins was used for preparation of blood smears. Smears were air dried, fixed in methanol and stained with Giemsa (Levine, 1985).

Indirect fluorescent antibody technique (IFAT). All sera were tested by IFAT against $T$. annulata. Schizont antigen was prepared according to (Burridge and Kimber, 1972). The 
technique adopted for IFAT was described by (Burridge, 1971) using rabbit antibovine $\operatorname{IgG}$ fluorescent isothiocyanate (FITC).

Biochemical analysis. Serum samples were subjected to biochemical examination for total proteins, albumin, total direct bilirubin, L- $\gamma-$ glutamyl-transferase, aspartat amino trasferase, sodium, potassium, chloride, iron and magnesium according to (Weichselbaum, 1946; Doumas et al., 1971; Walter and Gerade, 1970; Persijn and Vanderslik, 1976; Trinder, 1951; Sunderman and Sunderman, 1958; Schönfeld and Lowellen, 1964; and Husdan, 1968) respectively.

Tick identification. All visible ticks were removed and preserved in $70 \%$ alcohol. Ticks were identified according to (Hoogstraal, 1956).

Treatment. Naturally infected animals were treated with single dose of Buparvaquone (Butalex) (Schering Plough Animal Health) by $\mathrm{i} / \mathrm{m}$ injection at a rate of $2.5 \mathrm{mg} / \mathrm{kg}$, b.wt $(1 \mathrm{ml} /$ $20 \mathrm{~kg}$. Bwt) in neck muscles.

\section{Results and Discussion}

Tropical theileriosis or Mediterranean coast fever caused by Theileria annulata is one the most important diseases of cattle in Egypt, representing a major threat to the expansion and improvement of livestock production. In the present study, the clinical signs of infected animals were pyrexia, anorexia, emaciation, enlargement of lymph nodes, and lacrimation (Fig. 1, 2). These signs were more prominent in cross breed than in native cattle. These results agreed with that of (Papdopoulos et al., 1999; Radostits et al., 2000; Saleh and Mahran, 2003 and Omer et al., 2003b) and this supports the suggestion that crossbreeds of cattle are more sensitive to theileriosis.

The seasonal prevalence of $T$. annulata infection using blood smears examination showed that infection rate of tropical theileriosis in cross-breed cattle was higher than that of native cattle $40.3 \%$ and $29.4 \%$ respectively (Table 1). The peak of infection of crossbreed cattle was recorded in summer $42.8 \%$, while autumn season recorded the highest infection rate of native cattle $35 \%$. Similar results were recorded by (Mahmoud, 1991; Farah, 1995 and Mahmoud, 1996). Many authors recorded different infection rates; $15 \%$ (Bansal et al., 1987), 15.7\% (Handemir and Dik, 1998) 16.5\% (EL-Metennawy, 2000). These results suggested that imported pure-breed or crossbreed cattle are more sensitive to theileriosis than native breeds which have the ability to limit the macroschizont index (Preston et al., 1992; Papdopoulos et al., 1999; Bakheit and Latif, 2002 and Saleh and Mahran, 2003).

Results of seroprevalence of $T$. annulata revealed that $(80.7 \%)$ of cross-breed cattle were found harboring antibodies against $T$. annulata with maximum rate of infection in autumn season $(86.6 \%)$, where as, $(70.5 \%)$ of native cattle were positive by IFAT. Summer season recorded the peak of $T$. annulata antibodies (78.9\%). Similar results were recorded by (ELBahy, 1986 and Abd EL-Kader, 1991 and 1995) who observed that maximum infection rate occurred during summer and autumn seasons. Variable infection rates were recorded by many authors; 90\% (Bansal et al., 1987), 71.9\% (Hamed, 1993), 40\% (D'Oliveira et al., 1997), 27.2\% (Handemir and Dik, 1998), 4\% (Lawal et al., 1998), 31\% (Eren et al., 1998), and $72.6 \%$ (Manish et al., 2001). Such variations may be due to breed difference, immune status of the animals and prevalent tick species. In conclusion IFAT constitutes a valid serodiagnostic technique for use in epidemiological investigations and surveillance in order to explore latent infections that may be missed by blood film examination. (Fig. 4, 5)

With respect to tick infestation, the investigated cattle harbored Hyalomma anatolicum. The overall rate infestation of both breeds was $65.6 \%$; crossbreed infestation rate was $72.4 \%$ while that of local breed was $58.8 \%$. The obtained results showed that, the highest infestation rate of crossbreed $(80 \%)$ and local $(65 \%)$ cattle was achieved in autumn (Table 3$)$.

On the other hand, the minimum infestation rate in crossbreed cattle was recorded in winter $(60 \%)$, while summer was the season of lowest infestation rate of local cattle $(52.6 \%)$. Many authors reported different infestation rates of $H$. a. anatolicum 6.04\% (Ayden, 2000), 1.4\% (ELKammah et al., 2001), 6.7\% (Mazyad and Khalaf, 2002) and 61.1\% (Razmi, 2003). Such variations were attributed to variation in the nature of investigated areas and breed of cattle. They found that crossbreed and pure-breed cattle were highly susceptible to tick infestation that agreed with our results.

(Liebisch et al., 1984 and Abdel-Rahman et al., 1989) reported that H. a. anatolicum was the prominent species of ticks occured in all domestic animals, they added that $H$. $a$. anatolicum is the tick species which serves as a vector of Mediterranean theileriosis ( $T$. annulata) under natural condition in Egypt. 

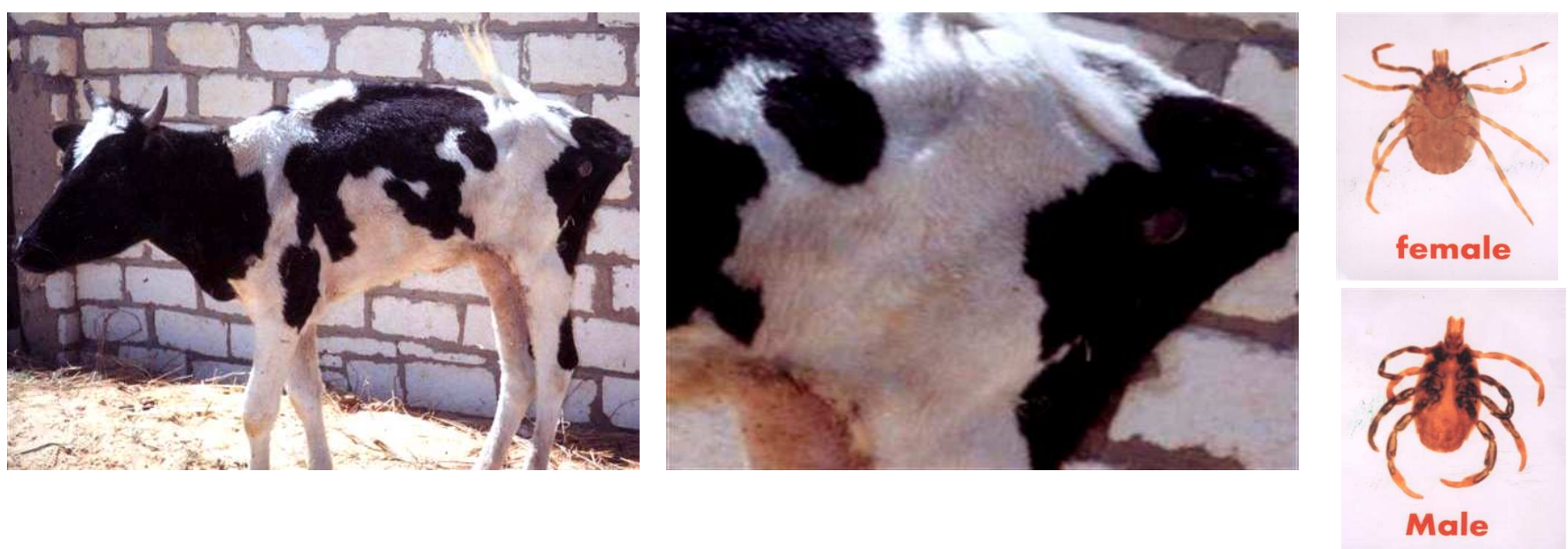

Fig. $(1,2,3)$ : 1 year old cross breed calf infected with theileriosis showed pronounced emaciation and enlarged prefemoral lymph node .There is ticks infestation $(H$. a.anatolicum) on the perneal region.

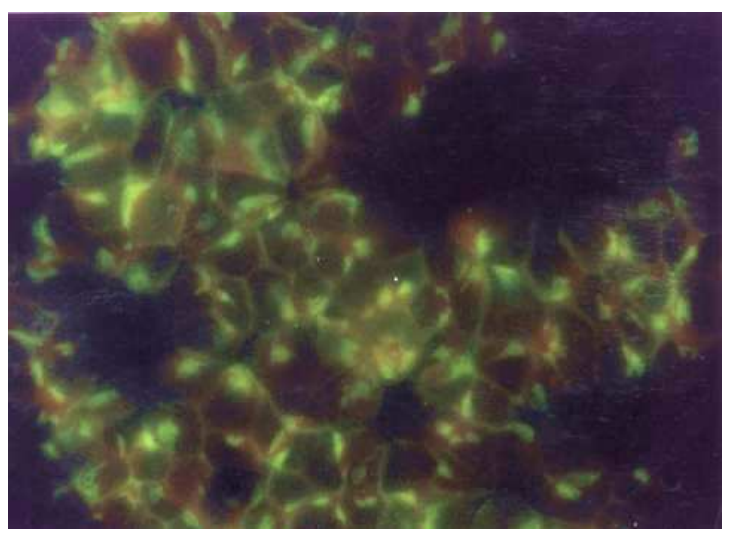

Fig. (4): Postive IFT reaction of T. annulata Schizont antigen with serum of infected animals

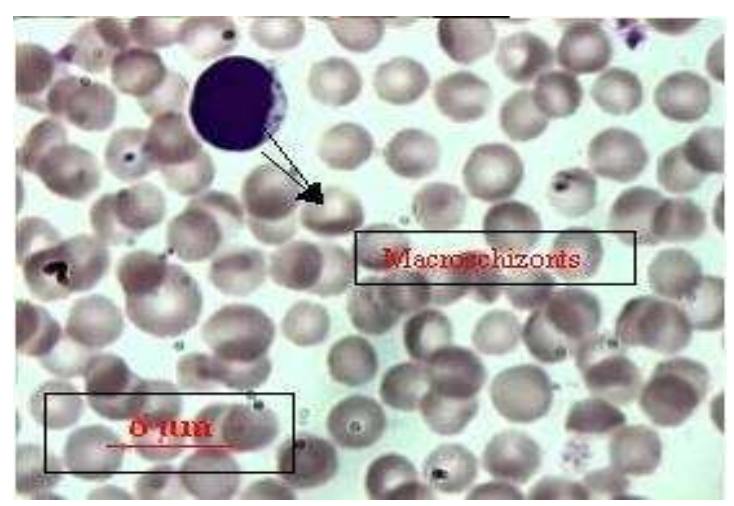

(A)

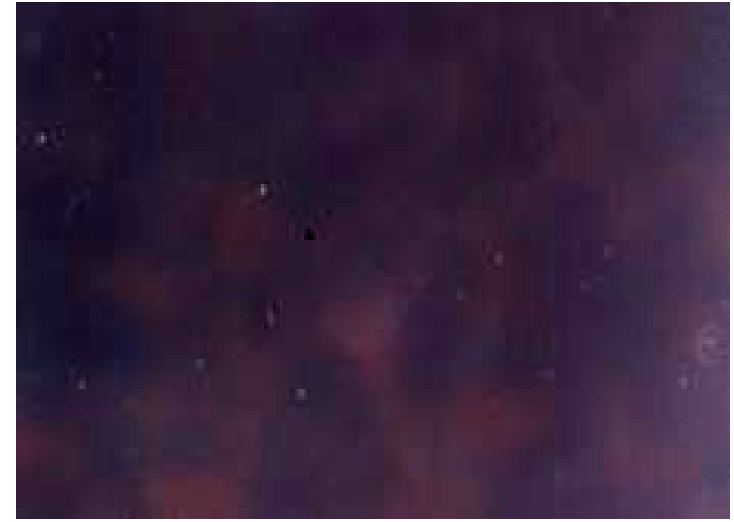

Fig. (5): Negative IFA reaction of T.annulata Schizont antigen with serum of control negative animals

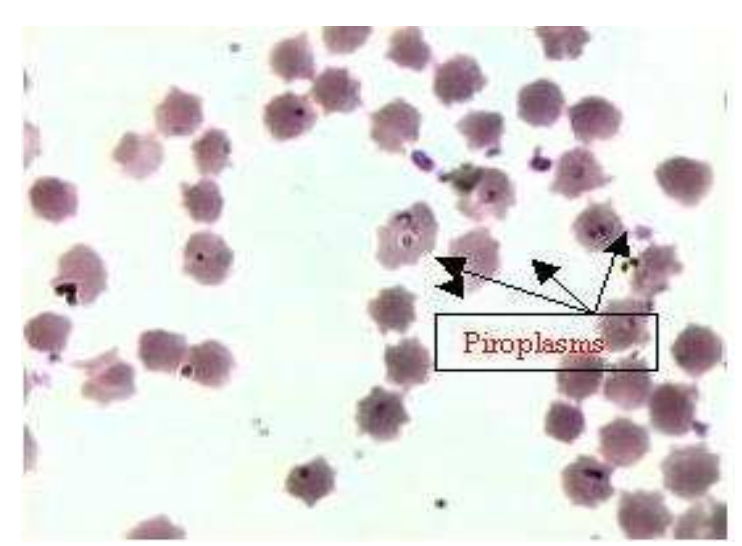

(B)

Fig. (6) Micrschizont (A) and (B) Piroplasms of T. annulata in blood smear of infected animals. 
Table (1): Seasonal prevalence of $T$. annulata among cattle using blood smears.

\begin{tabular}{lccccccccc}
\hline \multirow{2}{*}{ Season } & \multicolumn{3}{c}{$\begin{array}{c}\text { Total animals } \\
\text { examined }\end{array}$} & \multicolumn{3}{c}{ Cross breed } & \multicolumn{3}{c}{ Native breed } \\
\cline { 2 - 10 } & No. & + +ve & \% & No. & + ve & \% & No. & +ve & \% \\
\hline Winter & 25 & 9 & 36 & 15 & 6 & 40 & 10 & 3 & 30 \\
Spring & 32 & 11 & 34.3 & 13 & 5 & 38.4 & 19 & 5 & 26.3 \\
Summer & 33 & 12 & 36.3 & 14 & 6 & 42.8 & 19 & 5 & 26.3 \\
Autumn & 32 & 13 & 37.1 & 15 & 6 & 40 & 20 & 7 & 35 \\
Total & 125 & 42 & 36 & 57 & 23 & 40.3 & 68 & 20 & 29.4 \\
\hline
\end{tabular}

No. $=$ number of animals

+ ve. $=$ Positive.

$\%=$ Percent

Table (2): Seasonal prevalence of T.annulata among cattle using IFAT.

\begin{tabular}{cccccccccc}
\hline \multirow{2}{*}{ Season } & \multicolumn{3}{c}{$\begin{array}{c}\text { Total animals } \\
\text { examined }\end{array}$} & \multicolumn{3}{c}{ Cross breed } & \multicolumn{3}{c}{ Native breed } \\
\cline { 2 - 10 } & No. & + ve & \% & No. & + ve & $\%$ & No. & + +ve & $\%$ \\
\hline Winter & 25 & 17 & 68 & 15 & 10 & 66.6 & 10 & 6 & 60 \\
Spring & 32 & 24 & 75 & 13 & 11 & 84.6 & 19 & 12 & 63.2 \\
Summer & 33 & 28 & 84.8 & 14 & 12 & 85.7 & 19 & 15 & 78.9 \\
Autumn & 32 & 29 & 82.2 & 15 & 13 & 86.6 & 20 & 15 & 75 \\
Total & 125 & 98 & 78.4 & 57 & 46 & 80.7 & 68 & 48 & 70.5 \\
\hline
\end{tabular}

No. $=$ number of animals.

+ve. $=$ Postive.

$\%=$ Percent

Table (3): Seasonal prevalence of Hyalomm . anatolicum ticks.

\begin{tabular}{cccccccccc}
\hline \multirow{2}{*}{ Season } & \multicolumn{2}{c}{ Total animals examined } & \multicolumn{3}{c}{ Cross breed } & \multicolumn{3}{c}{ Native breed } \\
\cline { 2 - 10 } & No. & + ve & $\%$ & No. & + ve & $\%$ & No. & +ve & $\%$ \\
\hline Winter & 25 & 15 & 60 & 15 & 9 & 60 & 10 & 6 & 60 \\
Spring & 32 & 21 & 65.6 & 13 & 10 & 76.9 & 19 & 11 & 57.8 \\
Summer & 33 & 21 & 63.6 & 14 & 11 & 78.5 & 19 & 10 & 52.6 \\
Autumn & 32 & 25 & 71.4 & 15 & 12 & 80 & 20 & 13 & 65 \\
Total & 125 & 82 & 65.6 & 57 & 42 & 72.4 & 68 & 40 & 58.8 \\
\hline
\end{tabular}

No. $=$ number of animals

+ve. $=$ Positive.

In the current work, the mean values of blood serum total, direct and indirect bilirubin, L- gamma-glutamyl transferase, aspartate aminotransferase (AST) and creatinine revealed significant elevation in both theileria-infected native and cross breed cattle (Table 5). In contrary, total serum proteins showed significant decrease in mean values of both infected native and cross-breed cattle in comparison to control animals. These significant changes probably indicated inflammatory changes in hepatic and glomerular cells that in turn affected their functions. These results are in agreement with (Azza, 1995; Abou-ELHassan, 1997; Sandhu et al., 1998; Singh et al., 2001; Omer et al., 2003a; Saleh and Mahran, 2003 and Abou-EL Naga et al., 2004) reported similar results in camels infected with T. annulata. (Abou-EL Hassan, 1997 and Singh, 1998) reported several macroscopic and microscopic lesions especially in liver and kidneys of $T$. annulata infected calves resulting in hepatic and renal damages. These damages referred to proliferation and dissemination of the parasitized mononuclear macrophages in such organs or resulted from the excessive production of cytokines. No significant changes were recorded in mean values of albumin or globulin in infected cattle 
Table (4): Some serum biochemical parameters of cattle affected with tropical theileriosis.

\begin{tabular}{|c|c|c|c|c|c|c|}
\hline \multirow{2}{*}{ Item } & \multicolumn{3}{|c|}{ Native breed } & \multicolumn{3}{|c|}{ Cross breed } \\
\hline & Control & Infected & Treated & Control & Infected & Treated \\
\hline $\begin{array}{c}\text { Total bilirubin } \\
\mathrm{mg} / \mathrm{dl}\end{array}$ & $0.299 \pm 0.016^{c}$ & $0.398 \pm 0.004^{\mathrm{a}}$ & $0.360 \pm 0.009^{\mathrm{b}}$ & $0.293 \pm 0.010^{\mathrm{c}}$ & $0.392 \pm 0.004^{\mathrm{ad}}$ & $0.364 \pm 0.010^{b d}$ \\
\hline $\begin{array}{c}\text { Direct bilirubin } \\
\mathrm{mg} / \mathrm{dl}\end{array}$ & $0.179 \pm 0.006^{b}$ & $0.234 \pm 0.013^{\mathrm{a}}$ & $0.188 \pm 0.006^{b}$ & $0.182 \pm 0.003^{b}$ & $0.235 \pm 0.012^{\mathrm{a}}$ & $0.219 \pm 0.013^{\mathrm{a}}$ \\
\hline $\begin{array}{c}\text { Indirect. } \\
\text { bilirubin } \mathrm{mg} / \mathrm{dl}\end{array}$ & $0.120 \pm 0.016^{\mathrm{bc}}$ & $0.164 \pm 0.010^{\mathrm{a}}$ & $0.171 \pm 0.011^{\mathrm{a}}$ & $0.110 \pm 0.007^{\mathrm{c}}$ & $0.157 \pm 0.013^{\mathrm{ab}}$ & $0.145 \pm 0.014^{\mathrm{abc}}$ \\
\hline $\begin{array}{c}\gamma \cdot \text { glutamyl } \\
\text { transeferse iu/l }\end{array}$ & $24.40 \pm 1.600^{\mathrm{b}}$ & $35.28 \pm 2.330^{\mathrm{a}}$ & $31.92 \pm 1.649^{b}$ & $21.60 \pm 1.568^{b}$ & $37.14 \pm 2.011^{\mathrm{a}}$ & $32.42 \pm 1.228^{\mathrm{a}}$ \\
\hline $\begin{array}{c}\text { AST } \\
\mathrm{iu} / 1\end{array}$ & $41.4 \pm 1029^{b}$ & $68.2 \pm 3.152^{\mathrm{a}}$ & $45.8 \pm 1.959^{b}$ & $41.6 \pm 1.208^{b}$ & $67.6 \pm 3.264^{\mathrm{a}}$ & $47.6 \pm 1.860^{\mathrm{b}}$ \\
\hline $\begin{array}{c}\text { Creatinin } \\
\mu \mathrm{mol} / 1\end{array}$ & $116.82 \pm 1.912^{c}$ & $131.52 \pm 4.677^{b}$ & $119.76 \pm 3.671^{\mathrm{bc}}$ & $120.26 \pm 3.057^{b c}$ & $149.00 \pm 4.351^{\mathrm{a}}$ & $128.58 \pm 4.026^{b c}$ \\
\hline $\begin{array}{l}\text { Total protein } \\
\text { gm/dl }\end{array}$ & $7.672 \pm 0.157^{\mathrm{abc}}$ & $6.850 \pm 0.237^{\mathrm{d}}$ & $7.200 \pm 0.213^{\mathrm{cd}}$ & $8.142 \pm 0.080^{\mathrm{a}}$ & $7.420 \pm 0.185^{b c}$ & $7.840 \pm 0.128^{a b}$ \\
\hline $\begin{array}{l}\text { Albumin } \\
\mathrm{gm} / \mathrm{dl}\end{array}$ & $3.808 \pm 0.169^{\mathrm{a}}$ & $3.208 \pm 0.095^{b}$ & $3.346 \pm 0.119^{b}$ & $3.950 \pm 0.127^{\mathrm{a}}$ & $3.126 \pm 0.094^{b}$ & $4.046 \pm 0.741^{\mathrm{a}}$ \\
\hline $\begin{array}{l}\text { Globulin } \\
\text { gm/dl }\end{array}$ & $3.864 \pm 0.159^{\mathrm{a}}$ & $3.642 \pm 0.174^{\mathrm{a}}$ & $3.854 \pm 0.171^{\mathrm{a}}$ & $4.192 \pm 0.120^{\mathrm{a}}$ & $4.294 \pm 0.120^{\mathrm{a}}$ & $3.790 \pm 0.760^{\mathrm{a}}$ \\
\hline $\begin{array}{l}\text { Sodium } \\
\mathrm{mmol} / 1\end{array}$ & $161.18 \pm 2.408^{\mathrm{a}}$ & $127.16 \pm 3.212^{\mathrm{d}}$ & $149.66 \pm 1.144^{b}$ & $163.24 \pm 2.943^{\mathrm{a}}$ & $120.80 \pm 0.755^{d}$ & $139.00 \pm 1.776^{\mathrm{c}}$ \\
\hline $\begin{array}{c}\text { Potassium } \\
\mathrm{mmol} / \mathrm{l}\end{array}$ & $10.4200 .749^{\mathrm{bc}}$ & $5.84 \pm .0545^{\mathrm{d}}$ & $13.14 \pm 1.47^{\mathrm{a}}$ & $10.74 \pm 0.586^{b}$ & $5.24 \pm 0.503^{d}$ & $8.580 \pm 0.336^{\mathrm{c}}$ \\
\hline $\begin{array}{c}\text { Chloride } \\
\mathrm{mmol} / \mathrm{l}\end{array}$ & $110.38 \pm 1.238^{\mathrm{a}}$ & $109.36 \pm 1.648^{\mathrm{a}}$ & $111.48 \pm 0.717^{\mathrm{a}}$ & $110.42 \pm 1.590^{\mathrm{a}}$ & $109.14 \pm 2.059^{\mathrm{a}}$ & $110.94 \pm 0.613^{a}$ \\
\hline $\begin{array}{l}\text { Magnesium } \\
\mathrm{mg} / \mathrm{dl}\end{array}$ & $3.080 \pm 1.238^{\mathrm{a}}$ & $1.840 \pm 0.087^{\mathrm{c}}$ & $2.22 \pm 0.208^{\mathrm{cb}}$ & $3.00 \pm 0.130^{\mathrm{a}}$ & $2.00 \pm 0.063^{\mathrm{bc}}$ & $2.30 \pm 0.151^{\mathrm{b}}$ \\
\hline $\begin{array}{c}\text { Iron } \\
\mathrm{mmol} / 1\end{array}$ & $134.62 \pm 1.638^{\mathrm{a}}$ & $120.74 \pm 2.452^{b}$ & $131.42 \pm 0.810^{\mathrm{a}}$ & $136.32 \pm 1.172^{\mathrm{a}}$ & $124.00 \pm 2.844^{b}$ & $131.06 \pm 2.554^{\mathrm{c}}$ \\
\hline
\end{tabular}

Mean \pm Standard error.

$-\mathrm{a} b \mathrm{c}$ d Denotes significant differences from their respective control at $\mathrm{p} \leq 0.05$.

Table (5): Blood films Examination of Treated Cases With Buparvaquone.

\begin{tabular}{ccccc}
\hline \multirow{2}{*}{ Days post-injection } & \multicolumn{2}{c}{ Parasitemia \% (Mean) } & \multicolumn{2}{c}{ Rectal temperature (Mean) } \\
\cline { 2 - 5 } & Native & Cross breed & Native & Cross breed \\
\hline Day 0 & 8 & 12 & $40.0^{\circ} \mathrm{C}$ & $41.0^{\circ} \mathrm{C}$ \\
Day 1 & 3 & 5 & $39.0^{\circ} \mathrm{C}$ & $40.0^{\circ} \mathrm{C}$ \\
Day 2 & 1 & 3 & $38.4^{\circ} \mathrm{C}$ & $39.0^{\circ} \mathrm{C}$ \\
Day 5 & 0.1 & 0.5 & $38.0^{\circ} \mathrm{C}$ & $38.0^{\circ} \mathrm{C}$ \\
Day7 & 0 & 0 & $38.0^{\circ} \mathrm{C}$ & $38.0^{\circ} \mathrm{C}$ \\
\hline
\end{tabular}


compared to control. Ozan et al. (1999) reported non-significant changes in both total protein and albumin means values. On the other hand, (Byeong et al., 1992) reported significant increase in total protein with a significant decrease in albumin values in $T$. annulata infected Korean cattle. Sodium, potassium, magnesium and iron means values were significantly decreased in both native and crossbred cattle than that of control one. The same results were recorded by (Sandhu et al., 1998 and Omer et al., 2003). Buparvaquone (Butlex) treatment was effective against both stages of $T$. annulata (schizont and piroplasms) and succeeded to control fever as temperature returned to normal range by $7^{\text {th }}$ day posttreatment. These results coincided with (Dhar et al., 1990; Mahmoud, 1996; and Abou-ELNaga et al., 2004). Also the drug was helpful in returning some serum elements to its normal values especially in native but not in crossbred cattle.

In conclusion, theileriosis is one of the most serious tick borne protozoan parasitic diseases of cattle in Egypt. In general, mortality, morbidity and serum biochemical changes of $T$. annulata infection are much higher in crossbreed than native animals. The conventional methods of control of bovine theileriosis include chemoprophylaxis and treatment of clinical cases in addition to rigorous dipping protocols for control of insect vector. These operations require expensive charges making them too costly and difficult to standardize. From all the abovementioned reasons, there is a need for cattle immunization against theileriosis to reduce the losses resulted from such important disease.

\section{References}

Abd EL-Kader, M. H. (1991): Studies on theileriosis in cattle and buffaloes. M. V. Sc. Thesis Fac. Vet. Med. Zag. Univ., Egypt.

Abd EL-Kader, M. H. (1995): Epidemiological and immunological studies on bovine tropical theileriosis. Ph. D. Thesis Fac. Vet. Med., Zag. Univ. , Egypt.

Abel-Rahman, M. S.; Fahmy, M. M.; Ashmawy, K.; ElNimr, M. M. and Bahi, M. M. (1989): A review on the works done for the preparation of a vaccine against Theileria annulata Egyptian strain. Res. Vet. Sci., 13: 451460.

Abou- El Hassan, L. A. M. (1997): Clinicopathological study of theileriasis in New-Valley. M. Vet. Sc. Thesis, Fac. Vet. Med. Assiut Univ., Egypt.

Abou-El Naga, T. R.; Abd El-Baky, S. M. A. and Abdou, T. A. (2004): Theileriosis of camels (Camelus dromedarius) associated with infestation rate and control to camel ticks species (Hyalomma spp. Family: Ixodidae) in Egypt. $3^{\text {rd }}$ Int. Con. Anim., Poul. Fish Prod. Health in Desert Areas, North Sinai, Egypt.
Anon (1997): Theileriosis in OIE Manual Standards for Diagnostic Kafer-EL-Sheikh Tests and Vaccines $3^{\text {rd }}$ ed., Office International des Epizooties, Paris, France. pp. 321330.

Aydn, L. (2000): Distribution and species of ticks on ruminants in the southern Marmara Region. TurkiyeParazitoloji-Dergisi., 24 (2): 194-200.

Azza, M. A. (1995): Studies on some biochemical changes associated with blood parasite infection in cattle. Ph. D. Thesis Fac. Vet. Med., Kafer-EL-Sheikh Univ., Egypt.

Bakheit, M. A. and Latif, A. A. (2002): The innate resistance of Kenana cattle to tropical theileriosis (Theileria annulata infection) in the Sudan. Annals of the New York Academy of Sciences, 969: 159-163.

Bansal, G. C.; Ray, D.; Srivastava, R. V. N. Subramanian, G. (1987): Seroprevalence of bovine theileriasis in some farms in India. Ind. J. Anim. Sci., 57 (5): 366-368.

Burridge, M. (1971): Application of the indirect fluorescent antibody test in experimental east coast fever (T. parava infection of cattle). Res. Vet. Sci., 12: 338-341.

Burridge, M. and Kimber, C. D. (1972): The indirect fluorescent antibody test for experimental east coast fever (T. parava infection of cattle). Evaluation of cell culture schizont antigen. Res. Vet. Sci., 13: 451-455.

Byeong, K. B.; Byeong, S. K.; In, H. C.; Ki, C. Y.; Richard, H. and Ibulaimu, K. (1992): Immunogenicity and protective efficacy of solubilized merozoite-enriched Theileria sergenti immunogens. П: Protection against natural exposure under field conditions. The Kor. J. Parasitol., 30 (3): 201-208.

Dhar, S.; Malhotra, D. V.; Bhushan, C. and Gautam, O. P. (1990): Chemotherapy of different stages of experimentally induced bovine tropical theileriosis with buparvaqone. Ind. Vet. J., 67: 7 598-602.

D'Oliveira, C.; Jacquiet, P.; Jongejan, F. and Van-derWeide, M. (1997): Detection of Theileria annulata by PCR in ticks (Acari : Ixodidae) collected from cattle in Mauritania. Exper. Appl. Acarol, 21: 5, 279-291.

Doumas, B. T.; Watson, W. A. and Biqqs, H. G. (1971): Albumin standard and measurement of serum albumin with bromocresol green. Clin. Chem. Acta., 31: 87-96.

EL-Bahy, N. M. (1986): Some studies on ticks and tickborne diseases among ruminants in Fayoum Governorate. M. V. Sc. Thesis Fac. Vet. Med. Cairo Univ., Egypt.

El-Kammah, K. M.; Oyoun, L. M. J.; El-Kady, G. A. and Shahy, S. A. (2001): Investigation of blood parasites in livestock infested with argasid and ixodid ticks in Egypt. J. Egypt. Soci. Parasitol., 31 (2): 365-371.

El-Metenawy, T. M. (2000): Prevalence of blood parasites among cattle at the central area of Saudi Arabia. J. Protozool. Res., 10 (1): 6-13.

Eren, H.; Ozlem, M. B.; Sert, H. and Kaplan, A. (1998): The prevalence of Theileria annulata (Dschunkowsky \& Luhs) in cattle of the Aydin area. Acta Parasitologica Turcica, 22 (2): 177-179.

Farah, A. W. (1995): Some immunological studies on Theileria annulata infection in cattle in Egypt. Ph. D. Thesis, Cairo Univ., Egypt.

Hamed, Y. G. (1993): Studies on theileria protozoan among cattle in Behera Province. M. V. Sc. Thesis Fac. Vet. Med. Alex. Univ., Egypt.

Handemir, E. and Dik, B. (1998): Prevalence of theileriosis in cattle and its vector ticks in Konya Province. Veterinarium, 9 (1): 32-38.

Harfoush, M. A. (2001): Some studies on blood parasites in both cattle and tick victor. $6^{\text {th }}$ Sci. Cong. Egypt. Soci. Cattle Dis., Assiut, Egypt. 
Hoogstraal, H. (1956): African Ixodoidea, Vol. 1, Ticks of the Sudan. Research Report NM. 005050.29.07, US. Naval Medical Research Unit No. 3 Cairo, Egypt.

Husdan, H. (1968): Determination of serum creatinine. Clin. Chem., 14: 222-238.

Lawal, I. A.; Folaranmi, D. O.; Asselbergs, M.; Perie, N.; Okoro, J. E.; Bale, J. S. and Musa, B. (1998): Studies on prevalence of bovine theileriosis in Nigeria using the immuno-fluorescent antibody (IFA) test and microscopic detection technique. Niger. Vet. J., 19: 53-60.

Levine, N. D. (1985): Veterinary Protozoology. Iowa State Univ. Press, pp. 365.

Liebisch, A.; Abel-Rahman, M. S. and Hoogstraal, H. (1984): Studies on the occurrence and veterinary significance of ticks domestic animals in Egypt. A project report in: Recent German Research on problems of parasitology, animal health and animal breeding in the tropics and sub tropics. pp. 74-84.

Mahmoud, M. M. (1996): Studies on blood parasites in cattle in Suez Canal area. M. V. Sc. Thesis, Fac. Vet. Med. Suez Canal Univ., Egypt.

Mahmoud, S. Z. (1991): Studies on blood parasites in cattle. M. V. Sc. Thesis, Fac. Vet. Med. Beni- Suef, Cairo Univ., Egypt.

Manish, K.; Sandeep, D.; Anju, M.; Neeraj, D.; Malhotra, D.; Sangwan, A.; Nichani, A.; Kumar, M.; Dhawan, S.; Manuja, A.; and Dilbahi, N. (2001): Comparison of indirect immunperoxidase test with indirect fluorescent antibody test for detection of antibody titers against Theileria annulata. J. Immunol. Immunopathol., 3 (2): 36-40.

Mazyad, S. A. M. and Khalaf, S. A. A. (2002): Studies on Theileria and Babesia infecting live and slaughtered animals in Al-Arish and El-Hasanah North Sinai Governorate, Egypt. J. Egypt. Soci. Parasitol., 32 (2): 601610.

Norval, R. A. I.; Perry, B. D. and Young, A. S. (1992): The epidemiology of theileriosis in Africa. San Diego: Academic Press, pp. 481.

Omer, O. H.; El-Malik, K. H.; Magzoub, M.; Mahmoud, O. M.; Haroun, E. M.; Hawas, A. and Omar, H. M. (2003a): Biochemical profiles in Friesian cattle naturally infected with Theileria annulata in Saudi Arabia. Vet. Res. Comm., 27 (1): 15-25.

Omer, O. H.; Haroun, E. M.; Mahmoud, O. M.; ElMalik, K. H.; Abdel-Magied, E. M. and Magzoub, M. (2003b): Parasitological and clinico-pathological profiles in Friesian cattle naturally infected with Theileria annulata in Saudi Arabia. J. Vet. Med. B., 50 (4): 200-210.

Ozan, S. T.; Yaralioğlu, S.; Yilmaź, S.; Özer, E.; Şaki, C. E. and Sevgili, M. (1999): GSH-PX G6PD and arginase activities and some biochemical parameters in cattle infected with Theileria annulata. Turk. J. Vet. Anim. Sci., 23: 553-557.
Papadopoulos, B.; Maroli, M.; Uilenberg, G. and Cavacappa, S. (1999): Cattle and small ruminant piroplasmosis in Macedonia, Greece. Proceeding of the workshop on tick-borne diseases of livestock in the Mediterranean area, Palermo, Italy, Parassitologia- Roma, 41 (1): 81-84.

Payne, W. J. A. and Wilson, R. T. (1999): An Introduction to Animal Husbandry in the Tropics, $5^{\text {th }}$ ed. Blackwell Science Ltd.

Persijn, J. P. U. and Vanderslik, W. (1976): J. Clin. Biochem. 14: 421.

Preston, P. M.; Brown, C. G.; Bell-Sakyi, L.; Richadson, W. and Sanderson, A. (1992): Tropical theileriosis in Bos taurus and Bos taurus cross Bos indicus calves: response to infection with graded doses of sporozoites of Theileria annulata. Res. Vet. Sci., 53: 230-243.

Radostits, O. M.; Blood, D. C. and Gay, C. C. (2000): Veterinary Medicine, $8^{\text {th }}$ ed. Baillier Tindall, London, 1230. Razami, G. R.; Hosseini, M. and Aslani, M. R. (2003): Identification of tick vectors of ovine theileriosis in an endemic region of Iran. Vet. Parasitol., 166 (1): 1 - 6.

Rosenberger, G. (1979): Clinical examination of cattle. Verlag paul Parey. Berlin and Hamburg.

Saleh, M. A. and Mahran, O. M. (2003): Parasitological and biochemical studies on acute tropical theileriosis in neonatal indigenous and Friesian claves in the Egyptian Oases. $7^{\text {th }}$ Sci. Cong., Egypt. Soci. Cattle Dis. Assiut, Egypt, pp. 126-138.

Sandhu, G. S.; Grewal, A. S.; Singh, A.; Kondal, J. K.; Singh, J. and Brar, R. S. (1998): Haematological and biochemical studies on experimental Theileria annulata infection in crossbred calves. Vet. Res. Comm., 22: 347354

Schönfeld, R. G. and Lowellen, C. S. (1964): Clin. Chem. Biochem., 10: 533.

Singh, A. (1998): Clinicopathological studies on experimental Theileria annulata infection in crossbred calves. M. V. Sc. Thesis, Punjab Agric. Univ.

Singh, A.; Singh, J.; Grewal, A. S. and Brar, R. S. (2001): Studies on some blood parameters of cross-bred calves with experimental. Theileria annulata infection. Vet. Res. Comm., 25: 289-300.

Sunderman, F. W. Jr. and Sunderman, F. W. (1958): Am. J. Clincpathol., 29: 95.

Trinder, P. (1951): Analyst. 76: 596.

Walter, M. and Gerade, H. (1970): Microchem. J. 15, 231.

Weichselbaum, P. E. (1946): Determination of total protein. Am. J. Clin. Pathol., 16: 40.

Yadav, C. L and Sharma, N. N. (1986): Changes in blood chemical components during experimentally induced Theileria annulata infections in cattle. Vet. Parasitol., 21 (2): 91-98. 